DEBATE / DEBATE

The challenges of critical epidemiology and responses of capitalism to their reproductive difficulties: the cybersphere case*

\title{
Os desafios da epidemiologia critica e as respostas do capitalismo às suas dificuldades de reprodução: o caso da esfera cibernética
}

\author{
Cassia Baldini Soares'
}

Once more, Jaime Breilh shows his opinion on the reality challenges to epidemiology ${ }^{1}$. We have been in touch with the author's texts since the Annals from the First Brazilian Congress of Epidemiology - Epidemiology and Social Inequality: The Challenges of the 20th Century End, from 1990. In such space, Breilh ${ }^{2}$ was worried with the "destructive and healthy" processes that correspond to unequal forms of urban space occupation in Latin America; therefore, he suggested an analysis based on critical epidemiology. In addition, he showed that the urban social space could include mediators of social reproduction from social classes, who "function as assets that promote health or as destructive forces that deny life and promote life deterioration and death".

The new referred by the author in that space was the "new face of misery", which was settled in Latin America during the seventies due to the cycle of capitalism crisis, and that highlighted social inequalities and contradictions, creating changes in life standards and transformations in the State behavior. "The increasing concentration and monopolization of the productive structure marked even more the structural heterogeneity of Latin-American countries and was manifested in an epidemiological heterogeneity"2.

Thus, the author ${ }^{2}$ showed how the crisis contributed to the remarkable deterioration of social reproduction conditions of social classes, which would be in the foundation of health "destructive processes". Work and life conditions were degraded mainly in Latin America, as well as the redistributive role of the State, besides the loss of political and claimable action and of workers' human rights defense.

Universidade de São Paulo - São Paulo (SP), Brazil.

Corresponding author: Cassia Baldini Soares. Avenida Dr. Enéas de Carvalho Aguiar, 419. Cerqueira Cesar. CEP: 05403-000. São Paulo (SP), Brasil. E-mail: cassiaso@usp.br.

${ }^{*}$ Commentary on the article "Epidemiology of the $21^{\text {st }}$ century and cyberspace: rethinking the theory of power and social determination of health," by Jaime Breilh, for the journal Revista Brasileira de Epidemiologia. 
Health challenge was focused especially on:

- annulling the preventive and curative system and seeking actions on social determination of the health-disease process, that is, on the social reproduction where the crisis got worsen;

- transforming the health services by removing its discriminative and classic character;

- eliminating the relation between access to services and "purchase capacity and strategic importance that populations have to produce entrepreneurs and control of power"2.

The challenges pointed out by the author are still current. It is a fact that the reductionisms established by the preventive and curative equation remain dominant in the recent capitalism. This is clearly seen in the discipline recipes of behavior change that are transmitted by the health sector, as well as in the medications prescribed to all kinds of problems that life and social relations present. Such prescription is based on the idea that capitalism is an immutable system in its essence that provides opportunities to everyone, with the need of some adjustments in some unfair cases. Thus, we need to take all efforts individually to avoid risk groups, which come from genetic heritance and unhealthy behaviors, such as drinking too much, smoking, eating junk food, or living sedentarily, among others. The rules effusively emphasize that each subject has the autonomy to promote changes in his/her life $^{3}$. The comparison of markers from the so-called healthy life is part of our sociability in different social life spaces, such as cholesterol and glycaemia levels; body mass index; kilometers run per day; running speed; ingested calories; medications and daily food supplements; results of diets from the latest trend; exercises with good reputation for biceps / triceps etc.; prices and availability of organic food, and so on. A quick look at Facebook can also testify these elements regarding virtual sociability.

Recently, based on the collective health criticism, we acknowledge that the historic hygienist policies and practices under the domain of the traditional public health, are mixed with the preventive and curative policies and practices that depend on the health industry and are spread through the modern public health; the public health of risk factors and of the responsible individual's choice upon scientific evidence from risk epidemiology ${ }^{3}$.

Now, as in the past, health has the challenge of discussing the social reproduction domains worsened by the crisis. It is worth noting this is not effectively a capitalism crisis, but capitalist difficulties of reproduction, which are manifested as cycles in history ${ }^{4}$. Worsening of reproduction difficulties in the current accumulation regimen, which Viana ${ }^{5}$ calls integral, is expressed in toyotist forms of work organization, neoliberal state's actuation and neo-imperial international affairs. Hence, we must increase exploration and productivity rate, use secondary forms of exploration, and mine the labor rights. After the 2008 financial crisis, new difficulties of reproduction from the integral accumulation regimen have been responded by even more restricted policies, and the neoliberal State has decreased social expenses, as well as increased its repressive role 4 . The "productive restructuration," marked by subcontracting, causes several processes of insecurity and defenselessness, makes jobs become precarious, and increases poverty ${ }^{5}$.

As part of the group with subordinated capitalism countries, fighting against the impact on health state policies of the successive forms created by capitalism to be reproduced is 
also a challenge that remains in Latin America. It is known that countries of subordinated capitalism need to transfer surplus value to the imperialist block. Therefore, in these countries, the State conducts it more subordinately: the policies for labor rights destruction; the processes of sectors privatization that were once public and became an object of profit; the financial policies for adjustments; and the focalized state policies ${ }^{4}$.

This conjuncture shows that old challenges from the capitalist exploration, which have already been very well described by the critical epidemiology of Engels ${ }^{6}$ in England of the $21^{\text {st }}$ century, are still present. In addition, the resistance and fight paths have been tracked down, at least in Brazil, both by workers, who know the wastages from labor toyotist organization, and by organized groups of the population that recognize the wastage from the loss of rights and health privatization ${ }^{4}$.

In the text provided now by Jaime Breilh ${ }^{1}$, new challenges presented to "epidemiologies that are positioned as emancipators" are shown. An interesting distinction could be provided here, given that the emancipation concept has many meanings in the large literature that mentions expression, sometimes considered in the capitalist perspective such as autonomy about social institutions or in the radicalism of expression, as the process of understanding the essence of exploration, freedom from exploration mechanisms, and development of human capacity through praxis. I understand the author shows his opinion on a critical epidemiology based on the historical and dialectical materialism. Therefore, the emancipating epidemiology would be an instrument able of unravelling the mediations between the wider social structure and the wastage processes, and of denouncing the essential mechanisms, those found in the healthdisease process basis, in such a way that such proposal would be of overcoming capitalism.

In our interpretation, for sure, emancipating epidemiology would not fit as risk epidemiology, but it could be considered, on the other hand, as the one that performs the reading of health social determinants and therefore would have the power of helping in showing some mediators that cause wastages in work and life. In this chase, the challenge would be to improve these mediations like provide more income, or work qualification, among many others, which regard the focalized programs, always dependent on the capitalist State.

The author points out that new challenges for critical epidemiology would be those indicated by new forms of life domination and conditioning, which are extended to the cybernetic sphere ${ }^{1}$.

Breilh $^{1}$, in the presented text, calls this moment as "Accelerated capitalist State of accumulation," defined by the confluence of three acceleration mechanisms: use of technologies that facilitate the extraction of surplus value; fraudulent use of vital resources; and profiting from states of social shock. The author exposes concrete elements of this moment, which I mention among them the notions of: cybernetic space that functions as a sphere of social control and massification of behaviors; virtual spaces that are focused on propaganda and marketing with sales promotion, which many times are done dishonestly; robbery and use of private data; massive sale of antivirus programs and other instruments of protection against cybernetic attacks; tendency of producing useful knowledge to the technological market as the main way to development. 
The author gives examples of concrete wastages forms from mediations shaped by cybernetic technologies, like those expressed in Snowden's case or referring to adolescents that commit suicide due to social network exposure or to Internet resources dependence, besides other manifestations of its - we could say, compulsive — use that could be associated with the current individualism, consumerism, and sociability ${ }^{1}$.

We have the same reading regarding wastages from the current capitalism configuration, more particularly, wastage that is expressed in drug abuse - a phenomenon that has been increasing recently with peculiar characteristics, and of which we analyze through mediation of the social value category. The harmful use of drugs, as well as the "bad" use of cybernetic technology, led by social values, would produce wastage processes whose root is in the current capitalism structure and dynamics. Thus, we have approached in other spaces ${ }^{3,7}$ that subjects' answer to the recent reproduction processes of capital expansion - which is improved to explore worker's vital energy — takes the advantage of a set of values that are apparently contradictory among themselves, like the competition to occupy work positions and to achieve the production standards desired by employers. This happens in a conjuncture of unreliable work and production of a huge reserve army. The consequence of such situation is the appearance of individual values of skills to win and leap over the opportunities. Consumerism, the chosen mechanism to build the feeling of fitting in the world, occurs through massification. Charity to the so-called excluded individuals allows the feeling of relief with regard to the scathing social differences, among others ${ }^{3,7}$.

Aspirations and projects are mediated by kinds of current reproduction of capitalism and, thus, external to subjects in this "postmodern" environment. Hence, the Internet, as a kind of social relation that happens through virtual interaction, reacts not only to the need of socialization but also of fast, concise, and useful information and to the need of a instantaneous and contingent consumerism ${ }^{3,7}$.

Great oligopolies take advantage of the socialization necessities created by recent work and life dynamics, and their power overcomes the force of manipulation and control of consumerism, reaching the sphere of the intimate life ${ }^{3}$. This might create some discomforts, which are expressed in civil rights and individual citizenship. Consequently, Souza ${ }^{8}$ notices that subjects feel as their privacies were invaded and claim for protection laws.

The Internet and social networks have been instruments of collective actions. Surfers organize and articulate movements via social networks, such as the known Flash Mobs, or fast mobilizations, especially in urban places ${ }^{8}$. This is also the case of "rolezinhos" in São Paulo, which was a movement that mobilized many adolescents from the outskirts to hang out in shopping malls. However, following the same direction with different objectives, we can notice the development of one of the most prominent mobilizations that do not follow the status quo, such as Occupy Wall Street (Occupy), a social movement that denounced the unequal distribution of wealth, using social media mainly as a kind of organization instrument ${ }^{9}$. Subjects all over the world spread and sign petitions against atrocities and injustices. A huge amount of movement, both of liberal predominance or of critical foundation, organized through social media has been seen in different countries, with varied objectives. 
The challenges of critical epidemiology, which is one of the most important instruments of collective health, like the case of "old" and "new" challenges indicated by Breihl ${ }^{1,2}$, are still complex and riveting. As previously mentioned and based on historical words from the author and many other authors of the collective health field, this instrument needs to be able to clearly show, before the dominant science, the relation between capitalist social dynamics and structure, the mediations and particular wastages of the social reproduction conditions from subjects, families, and groups that compose social classes. Besides exposing the social contradictions, this process might be able to mobilize political actions and transformation movements ${ }^{10}$.

On the basis of this context, we agree with the author ${ }^{1}$ that critical epidemiology should also accept the challenge of fomenting collective health and mobilization to fight for a safe and democratic network to keep an open, democratic, solidary, and non-mercantile character of cybernetic technologies and to increase their uses and stop private monopoly.

To do so, it will also be necessary to foment studies in the worker's health area in environments where the work of making feasible networks is completed, besides showing the challenges of correlating the work and life structural dimension to over-structural mediators chosen by capitalism and to the "new" wastages that mine the health-disease process and currently kill lives.

Finally, I salute the text, especially before the conjuncture in which scientific forms of reality apprehension and knowledge production are added through the ideology of theories fragmentation and through useful objectives for the technological market.

\section{REFERENCES}

1. Breilh J. Epidemiología del Siglo XXI y Ciberespacio: Repensar la Teoría del Poder y la Determinación Social de la Salud. Rev Bras Epidemiol 2015; 18(4): 965-974.

2. Breilh J. La pobreza urbana y la salud: una mirada desde la epidemiologia crítica. In: Anais do $1^{\circ}$ Congresso Brasileiro de Epidemiologia; 1990 set 2-6; Campinas (Br). Rio de Janeiro: ABRASCO; 1990; p. 281-302.

3. Soares CB. Consumo contemporâneo de drogas e juventude: a construção do objeto na perspectiva da Saúde Coletiva [tese livre docência]. São Paulo: Escola de Enfermagem, Universidade de São Paulo; 2007.

4. Campos CMS, Viana N, Soares CB. Mudanças no capitalismo contemporâneo e seu impacto sobre as políticas estatais: o SUS em debate. Saude Soc 2015; 24(Suppl 1): 82-91. doi: 10.1590/ S0104-12902015S01007.

5. Viana N. O capitalismo na era da acumulação integral. Aparecida: Idéias e Letras; 2009
6. Engels F. A situação da classe trabalhadora na Inglaterra. São Paulo: Boitempo; 2008.

7. Soares CB, Campos CMS. Consumo de drogas. In: Borges ALV, Fujimori E, orgs. Enfermagem e a saúde do adolescente na atenção básica. Barueri: Manole; 2009, p. 436-468.

8. Souza NL. Representações Culturais na Esfera Cibernética. Revista Sociologia em Rede 2012; 2(2): 47-56.

9. Conover MD, Davis C, Ferrara E, McKelvey K, Menczer F, Flammini A. The Geospatial Characteristics of a Social Movement Communication Network. PLoS ONE 2013; 8(3): e55957. doi: 10.1371/journal.pone.0055957.

10. Soares CB, Trapé CA, Yonekura T, Campos CMS. Marxismo, trabalho e classes sociais: epidemiologia crítica como instrumento da saúde coletiva. In: Carvalheiro JR, Heimann LS, Derbli M, orgs. O Social na Epidemiologia: um legado de Cecília Donnangelo. São Paulo: Instituto de Saúde, 2014, p. 119-147. 